\title{
A Survey of Market Orientation in Public and Nonprofit Organization (MO-PNPO) Research (2005-2015)
}

\author{
Ngatno \\ Doctoral Program of Social Science \\ Diponegoro University \\ Semarang, Central Java, Indonesia \\ (ngatno_fisip@yahoo.co.id)
}

\begin{abstract}
Over the recent years, the concept of market orientation has become an attractive avenue for research in marketing. However, despite an array of theories, a systematic framework investigating the role of market orientation in nonprofit organizations remains limited. Through the integration of concepts from market orientation literature, the study put a comprehensive model that describes the role of market orientation in public and nonprofit organization (MO-PNPOs).
\end{abstract}

Keywords—market orientation; public organization; non profit organization

\section{INTRODUCTION}

The marketing concept holds that the key to achieving organizational goals is to be more effective and efficient than competitors in identifying and in satisfying the needs of target markets (Kotler, 2003). Kohli \& Jaworski, (1990) and Narver \& Slater, (1990) articulated a theory of "market orientation", they describe as the implementation of the marketing concept. The work of Kohli \& Jaworski, (1990) and Narver \& Slater, (1990) were the first in a substantial stream of research in the 1990s that investigated the antecedents and outcomes of a business increasing its market orientation. The meaning and importance of MO has been studied extensively in the forprofit sector (e.g., Kohli \& Jaworski, 1990; Narver \& Slater, 1990), but it is a relatively new concept in the public and nonprofit sector. Therefore, the public and nonprofit sector still seems to be struggling with adopting a market orientation (Caruana et al. 1997).

The increasingly competitive environment being experienced by third the commercial, public and non-profit sector has led to the adoption of market orientation by various organizations. During the last 15 years there has been a significant increase in the number of public and non-profit organizations, because of the rapid changes in environmental conditions. As a result there is a growth in competition among organizations that operate in this sector. It is important to be able to build strong brand identity, image and personality in order to differentiate themselves in the growing nonprofit sector. A better understanding of how individuals make choices regarding public and nonprofit organization would be valuable to organizations in indentifying and communicating with their target markets more effectively. So the commercialization of public and nonprofit organizations through marketing mechanisms has recently become important.

This article deals with market orientation from the less studied perspective of public and nonprofit organizations. Public and nonprofit organizations have become increasingly aware of the advantages of market orientation-based management and have reformulated their strategies according to it in adjusting to demanding and evolving environments. Unlike a more traditional review which looks for specific key contributions and seminal pieces of literature, we track the overall growth in MO-PNPOs research and present an analysis of publication outlets and problem domains where the research was conducted. We take a close look at the impact of MOPNPOs-performance as well as the moderators and mediators of that impact. We introduce a conceptual model of MOPNPOs in order to organize the vast body of MO-PNPOs. This paper is to provide a sort of roadmap to those interested in gaining a better understanding of MO-PNPOs research. This is followed by an analysis of the overall growth, publication outlets, and problem domains MO-PNPOs research. Based on these analyses, we present a conceptual model capturing the relationships between the domains of MO-PNPOs research. This is followed by a discussion of some of the limitations of our research as well as directions for further research and some brief conclusions.

\section{Methodology}

In our study a wide range of literature sources has been used: journals and scientific articles. In order to identify a comprehensive article for inclusion in our survey we utilized a simple keyword search of available online journal databases. The following six online journal (Google Scholar; Science Direct; Emerald; Ebscohost; Proquest; and Springer) databases were searched with the major key word phrase, "market orientation on public sector" and "market orientation on nonprofit organisations" on December 31, 2015.

We started based on the descriptor 'market orientation'. The full text of each article was reviewed to eliminate those 
articles that were not actually related to MO-PNPOs. Only those articles that had been published in journals were selected, as these were the most appropriate outlets for market orientation for market orientation for public sectors or nonprofit organizations. Articles with no significant keywords and no publised on journal were neglected.

\section{Public And NonProfit Organization Definitions}

Given the intention to examine market orientation and organizational performance of the public and nonprofit organization, it is important to begin by defining what we mean by these term. Nonprofit organizations can be defined as: one that exists to provide for the general welfare of society, through the marshalling of appropriate resource and/ or the provision of physical goods and service.

The adoption of a distinctive market orientation by public and nonprofit organization became increasingly important during the 1980s and 1990s when both public and voluntary sectors were exposed to market mechanisms and business approaches (Balabanis, Stables, and Phillips 1997). Consequently, as public and nonprofit organizations are increasingly involved in competition for customer and competitor. In general terms, the public sector consists of governments and all publicly controlled or publicly funded agencies, enterprises, and other entities that deliver public programs, goods, or services. The concept of public sector is broader than simply that of core government and may overlap with the not-for-profit or private sectors. For the purposes of this guidance, the public sector consists of an expanding ring of organizations, with core government at the center, followed by agencies and public enterprises. Around this ring is a gray zone consisting of publicly funded contractors and publicly owned businesses, which may be, but for the most part are not, part of the public sector. Outside this clear public sector area is a gray zone, or boundary zone, with two types of organizations that might or might not be part of the public sector, that is: (1) state businesses are government owned and controlled businesses that sell goods or services for profit in the private market; (2) public contractors are legally independent entities outside government that receive public funding-under contract or agreement - to deliver public programs, goods, or services as their primary business. Due primarily to their limited public control, these organizations usually would be classified as notfor-profit or private sector entities.

\section{RESUlt AND Discussion}

\section{A. Trend of MO-PNPOs Research}

Although most of the MO literature is based on the forprofit sector (Shoham, 2006), the MO-performance link in the public and nonprofit organization is under-researched. Research in MO is not so prevalent in the public sector and non-profit organization as in the private sector. There has been an increase of interest in MO and public sector organizations such as police services, hospitals, library, and universities in the last decade. Rodolfo, A. Belén, \& Víctor, (2002) argue that the literature on the management of public and nonprofit organization concurs that MO should increase and improve their results (Balabanis et al., 1997), but the empirical evidence is scarce, unlike in profit organizations.

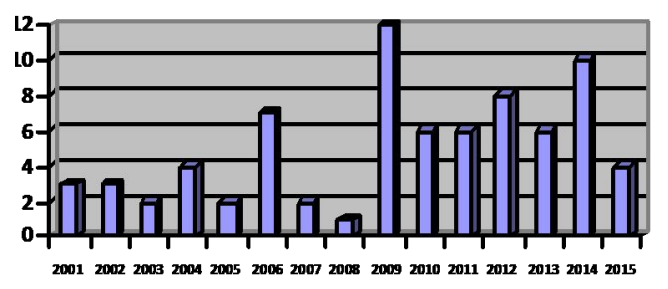

Fig. 1. The distribution of MO-PNPO articles by years

The distribution of articles published by year is shown in Fig. 1. Research output in MO-PNPOs has increased significantly since 2009 . There was a slight drop in 2010, and stabily until 2014. As can be seen in the figure 1, the overall growth trend is strong and steady. In the first eight years (2001-2008) there were 20 publications $(35.52 \%$ of the total), but from 2009 to 2015 the number of articles that discuss the MO-PNPOs more than twice (49 articles). These 69 MOPNPOs articles were published in a total of 6 sources. Table 1 includes a listing of the frequency of MO-PNPOs articles for each year included in the study. The three MO-PNPOs journals, are publised by Proquest, Emerald and Google scholar (almost $76.81 \%$ of the total articles).

\section{B. MO-PNPOs Issues}

The contemporary responsive and proactive market orientation literature (from its 'rediscovery' in 2004 onwards) deals with four issues: (a) the definition and measurement issue; focusing on the conceptualization of the construct. (b) the model issue; focusing on the antecedents and consequences of a market orientation. This literature deals with the causes and effects of MO-PNPOs.

A computerized search in scholarly academic databases for research in this context yielded few papers and the number of empirical papers. In this section, we provide an overview of the results of our search. Conceptual papers, our search identified 15 theoretical/ conceptual/case study articles about MO-PNPOs. As will become apparent, these papers share only two things in common-dealing with MO and the public and nonprofit organization context. In sum, the conceptual papers reviewed cover a diverse set of topics and do not seem to have much in common. In fact, their contribution is marginalized by being "one-shot" contributions with no theoretical thread to tie them together. Empirical papers, our search identified 54 empirical articles about MO-PNPOs. Similar to the assertion made about conceptual and theoretical papers above, we note that these papers have little in common in the way of country, conceptualization and operationalization of MO, sample used, and method of analysis. However, most identified a positive MO-performance link (as: Amparo, Alejandro, \& Manuel, 2001; Paarlberg, 2007; Zhou, Chao, \& Huang, 2009; Yulia \& Carmel, 2009; Rod \& Ashill, 2010; Hashim \& Abu Bakar, 2011; Walker, Brewer, Boyne, \& Avellanda, 2011; Mahmoud \& Yusif, 2012; Felgueira \& Rodrigues, 2012; Rodrigues, Pinho, \& Martins, 2013; etc). 


\section{The Model Issue of MO-PNPOs}

The next issue in MO-PNPOs research is the model issue. The model issue focuses on the antecedents and consequences of MO-PNPOs, as well as variables that might moderate the relationships between MO-PNPOs and their consequences. The current degree of MO-PNPO is expected to correlate with current performance. Amount of studies have researched the relationship between the degree of MO-PNPOs and performance. This relationship has been studied for public and non-profit organizations. The current degree of MO-PNPOs is expected to correlate with current performance. The dominant view is that an organization's degree of MO-PNPOs has a positive significant effect on performance (Amparo, Alejandro, \& Manuel, 2001; Paarlberg, 2007; Zhou, Chao, \& Huang, 2009; Yulia \& Carmel, 2009; Rod \& Ashill, 2010; Hashim \& Abu Bakar, 2011; Walker, Brewer, Boyne, \& Avellanda, 2011; Mahmoud \& Yusif, 2012; Felgueira \& Rodrigues, 2012; Rodrigues, Pinho, \& Martins, 2013; (Pinho, Rodrigues, and Dibb 2014); (Algarni and Talib 2014); (Gillett 2015) and satisfaction (Gainer and Padanyi 2005);(Modi and Mishra 2010); (Rod and Ashill 2010); (Hashim and Abu Bakar 2011); (Walker et al. 2011)(Modi 2012); (Casidy 2014); (Mainardes and Dos Cerqueira 2015)

Kohli \& Jaworski, (1990) state that the benefits of being market orientated may be greater for organizations in a competitive industry than for organizations operating in less competitive industries. Organizational factors are important precursors to market orientation (Kohli et al., 1993; and Narver \& Slater, (1990). Many researches shows that factors of MO-PNPO are: organization factor (Lin 2011); organizational factors, high level management, economic factors (Kowalik 2011); managerial attitude and group culture (Hashim and Abu Bakar 2011); top management, inter-departmental dynamic, organization system (Dwairi 2012); teaching, research and cultural diffusion (Flavián and Lozano 2006); Emphases, professional attitude size, entrepreneurship and perceive environmental (Amparo et al. 2001).

Mediator variables appear to play an important role in increasing the strength of the association between MO-PNPOs and performance. In fact, some of research argued that there may not be direct relationship between MO-PNPOs and performance, measure when a mediating is included in case that the relationship becomes insignificant. There are many mediator of MO-PNPO and performance: service quality (Hashim and Abu Bakar 2011); innovation (Choi, 2014; Algarni \& Talib, 2014).

\section{CONCLUSION}

This survey reviewed empirical articles related to market orientation of public and nonprofit organization (MO-PNPOs) from 2001 to 2015. It provided a guideline for scholars and practitioners. The study depicted a considerable leap research in MO-PNPOs since 2009 simultaneously to the universally growth. It showed that MO-PNPOs is a universal phenomenon. This survey found out that MO-PNPOs has been considered importantly for both public and nonprofit organization. This study concludes that it may have a direct relationship between implementing MO-PNPOs and performance and satisfaction.
Beside, in the relationship between MO-PNPO and performance, this survey pulled out the most common variables researched related to mediators and performance dimensions. To conclude, a framework prepared for researchers and practitioners who involve in the field of MO-PNPOs antecedent and consequences.

\section{REFERENCES}

[1] Algarni, Abdullah Mohammed M. and Noraini A. B. U. Talib. 2014. "Business Management Department Faculty of Management Universiti Teknologi Malaysia.” (2012).

[2] Ali, Kara, John E. Spillan, and Oscar W. DeShields. 2004. "An Empirical Investigation of the Link between Market Orientation and Business Performance in Nonprofit Service Providers." Journal of Marketing Theory and Practice 12(2):59-72.

[3] Amparo, Carvera, Molla Alejandro, and Sanchez Manuel. 2001. "Antecedents and Consequences of Market Orientation in Public Organization.” Eropean Journal of Marketing 35(11):1259-86.

[4] Balabanis, George, Ruth E. Stables, and Hugh C. Phillips. 1997. "Market Orientation in the Top 200 British Charity Organizations and Its Impact on Their Performance." European Journal of Marketing 31(8):583-603.

[5] Caruana, Albert, B. Ramaseshan, Michael T. Ewing, and Albert Caruana. 1997. "Australian Public Sector Market Orientation and Organizational Commitment Sector." International Journal of Public Sector Management 10(4):294-303.

[6] Casidy, Riza. 2014. "The Role of Perceived Market Orientation in the Higher Education Sector." Australasian Marketing Journal (AMJ) 22(2):155-63.

[7] Choi, S. 2014. "Learning Orientation and Market Orientation as Catalysts for Innovation in Nonprofit Organizations." Nonprofit and Voluntary Sector Quarterly 43(2):393-413.

[8] Dwairi, Musa. 2012. "Orientation In Public Sector In The Kingdom Of." 499-505.

[9] Felgueira, Teresa and Ricardo Gouveia Rodrigues. 2012. "Market Orientation of Teachers and Researchers in Higher Education Institutions: A New Approach." VIEŠOJI POLITIKA IR ADMINISTRAVIMAS PUBLIC POLICY AND ADMINISTRATION 11(4):703-18.

[10]Flavián, Carlos and Javier Lozano. 2006. "Organisational Antecedents of Market Orientation in the Public University System." International Journal of Public Sector Management 19(5):447-67.

[11]Gainer, Brenda and Paulette Padanyi. 2005. "The Relationship between Market-Oriented Activities and Market-Oriented Culture: Implications for the Development of Market Orientation in Nonprofit Service Organizations." Journal of Business Research 58(6):854-62.

[12]Gillett, A. G. 2015. "REMARKOR: Relationship Marketing Orientation on Local Government Performance." Journal of Services Research 15(1):97-130.

[13]Hashim, Fariza and Abdul Rahim Abu Bakar. 2011. "Antecedents and Consequences of Market Orientation in Non-Profit Organizations: Evidence From Malaysia." International Journal of Management \& Marketing Research (IJMMR) 4(3):95-105.

[14]Kohli, Ajay K., Bernard J. Jaworski, and Ajith Kumar. 1993. "MARKOR A Measure of Market Orientation." Journal of Marketing Research 30(4):467-77.

[15]Kohli, Ajay K. and Bernard. J. Jaworski. 1990. "Market Orientation the Construct, Proposition and Implication.pdf." Journal of Marketing 54(April): $1-18$

[16]Kotler, P. 2003. Marketing Management.

[17]Kowalik, Izabela. 2011. "Market Orientation and Its Antecedents in the Polish Local Governments." International Journal of Public Sector Management 24(1):57-79.

[18]Lin, Wen-bao. 2011. "Factors Affecting Hospital' S Adoption of a Market Orientation." 8(2):66-78.

[19]Mahmoud, Mohammed Abdulai and Baba Yusif. 2012. Market Orientation, Learning Orientation, and the Performance of Nonprofit

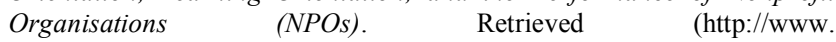
emeraldinsight.com/doi/abs/10.1108/17410401211249193 \nhttp://www.e meraldinsight.com/10.1108/17410401211249193). 
[20]Mainardes, Emerson Wagner and Alexandre Santos Dos Cerqueira. 2015. "Measuring the Internal-Market Orientation in the Public Sector." Public Organization Review.

[21] Modi, Pratik. 2012. "Market Orientation in Nonprofit Organizations: Innovativeness, Resource Scarcity, and Performance." Journal of Strategic Marketing 20(1):55-67.

[22]Modi, Pratik and Debiprasad Mishra. 2010. "Conceptualising Market Orientation in Non-Profit Organisations: Definition, Performance, and Preliminary Construction of a Scale." Journal of Marketing Management 26(5-6):548-69.

[23]Narver, John C. and Stanley F. Slater. 1990. "The Effect of Market Orientation on Business Profitability." Journal of Marketing (October):20-35.

[24] Narver, John C., Stanley F. Slater, and Douglas L. MacLachlan. 2004 "Responsive and Proactive Market Orientation and New Product Success." The Journal of Product Innovation Management 21(5):334-47.

[25]Narver, J. C., \& Slater, S. F. 1990. "The Effect of Market Orientation on Business Profitability." Journal of Marketing 54(April):1-18.

[26]Paarlberg, Laurie E. 2007. "The Impact of Customer Orientation on Government Employee Performance." International Public Management Journal 10(778384749):201-31.

[27]Pinho, J., A. Rodrigues, and S. Dibb. 2014. "The Role of Corporate Culture, Market Orientation and Organisational Commitment in Organisational Performance: The Case of Non-Profit Organisations." Journal of Management Development 33(4):374-98.
[28]Rod, Michel and Nicholas J. Ashill. 2010. "The Effect of Customer Orientation on Frontline Employees Job Outcomes in a New Public Management Context." Marketing Intelligence \& Planning 28:600-624.

[29]Rodolfo, Vázquez, del Río A. Belén, and Iglesias Víctor. 2002 "Consumer-Based Brand Equity: Development and Validation of a Measurement Instrument." Journal of Marketing Management 18(12):27-48.

[30]Rodrigues, Ana Paula, José Carlos Pinho, and Francisco Vitorino Martins. 2013. "The Impact of Market Orientation on Employee's Satisfaction and Commitment and on Organizational Performance: Application to the Local Public Sector." Revista Portuguesa de Marketing 30:18-35. Retrieved (http://repositorio.utad.pt/handle/ 10348/517)

[31] Shoham, a. 2006. "Market Orientations in the Nonprofit and Voluntary Sector: A Meta-Analysis of Their Relationships With Organizational Performance." Nonprofit and Voluntary Sector Quarterly 35(3):453-76.

[32] Walker, R., G. Brewer, George Alexander Boyne, and C. Avellanda. 2011 "Market Orientation and Public Service Performance: New Public Management Gone Mad?" Public Administration Review 707-17.

[33] Yulia, Yeni and Herington Carmel. 2009. "The Effect of Marketing Planning and Market Orientation on Higher Education Performance." ANZMAC 1-9.

[1] Zhou, Yanfeng, Paul Chao, and Guang Huang. 2009. "Modeling Market Orientation and Organizational Antecedents in a Social Marketing Context Evidence from China." International Marketing Review 25(3):256-74. 